\title{
Efficacy of Neem Tree (Azadirachta indica A. Jusieu) Extract on White Cabbage Aphid (Brevicoryne brassicae L. (Hem: Aphididae) Control in the Field
}

\author{
Amongi Evaline Stella ${ }^{1}$, Murongo Marius Flarian ${ }^{2} \&$ Mwine Julius Tedson ${ }^{3}$ \\ ${ }^{1}$ Agriculture-Supervisor Horticulture Section, Kakira Sugar Limited, Uganda \\ ${ }^{2}$ Uganda Martyrs University, Uganda \\ ${ }^{3}$ Ecological Organic Agriculture Initiative, Uganda Martyrs University, Uganda \\ Correspondence: Amongi Evaline Stella, Agriculture-Supervisor Horticulture Section, Kakira Sugar Limited, \\ Uganda. E-mail: stellaamongi@gmail.com
}

Received: January 14, 2017

Accepted: January 16, $2018 \quad$ Online Published: February 15, 2018

doi:10.5539/jas.v10n3p370

URL: https://doi.org/10.5539/jas.v10n3p370

\begin{abstract}
Neem tree extracts from root, bark and leaves have generally been used in the control of pests. The extracts' efficacy in the control of aphids in cabbages under smallholder farming systems formed the subject of the study. The dose of the admixture of the extract that effectively controlled aphids was determined through experimental methods that involved harvesting and crashing $0.1 \times 10^{-4}$ of Neem tree parts. The extract was fermented for 18-48 hours. Treatment tests solutions varied were $20 \mathrm{~mL}, 30 \mathrm{~mL}$ and $40 \mathrm{~mL}$ of the extract respectively in 10litres of water and applied to cabbage in the field at intervals of once a week, twice a week and once in 2 weeks in a triplicated completely Randomized Block Design. The treated plants were observed for average number of live aphids, number of dead aphids, degree of leaf perforation, leaf curls, stunting, and finally the yield of the cabbage visa vis treatments. Aphid counts at the concentration of $30 \mathrm{~mL}$ in $10 \mathrm{~L}$ of water were significantly lower for live aphids and higher for dead aphids $(\mathrm{P}<0.05)$, Although all treatments revealed significant differences from the control in terms of Aphid mortality, overall mean aphid counts showed a reduction in number (implying high mortality) with an increase in the concentration of Neem extract applied and cabbage vigour increased with increase in the frequency of admixture application, with a bi-weekly application producing significant results $(\mathrm{P}<0.05)$. High concentration $(40 \mathrm{~mL})$ more effectively controlled aphids but resulted in mild scorched leaves. Smallholder farmers should take advantage of the naturally available Neem tree concoctions of $30 \mathrm{mLs}$ in 10litres of water twice a week to keep aphid's population below the economic injury level.
\end{abstract}

Keywords: admixture, efficacy (dose and frequency), Neem tree extract, white cabbage aphids (Brevicoryne brassicae)

\section{Introduction}

Cabbage crop is highly susceptible to various insect pests of which aphids both grey aphids, B. brassicae (L.) and Green peach aphids, M. persicae (Sulzer) (Hemiptera: Aphididae) (Franke et al., 2009; Boyles et al., 2012). Aphids cause heavy damage by spreading virus diseases to the plant when it forms dense colonies on developing head, yielding losses of up to $70 \%$ if infestations are left untreated. Earlier work by Kakwenzire et al. (1997) showed that during the dry season both nursery and field crops of white cabbage were infested by B. brassicae, Diamondback moth (Plutella xylostella) and cabbage lopper (Trichoplusia ni). Some biological control activity has been observed in the field with Coceinelids wasps, lady birds beetles and Didegma species being the common natural predators of the above mentioned pest, however, biological control appears not to be sufficient during dry season. Aphid control in most farmers' fields is through the application of synthetic chemicals (Cornelius et al., 2006; Zachary, 2015). This approach addresses the economic aspect of sustainability by increased yields but leaves out the social aspects of human health and safety, as well as environmental friendliness of the ecosystem functioning. In Kakira region, the most common types of aphids that attack cabbage plants are grey aphids, B. brassicae (L.) and green peach aphids, M. persicae (Sulzer), with the grey aphids, B. brassicae (L.) being the strain of highest economic importance. This together with green peach aphids, 
M. persicae (Sulzer) they rage havoc in the area, their damage potential being exacerbated by the capacity to vector over 100 plant viruses, resulting in a wilting, deformation, premature leaf senescence, and retarded growth rate of the plant (Pegadaraju et al., 2005). There is therefore need to keep them under control.

Most farmers in Uganda and particularly in Kakira area use synthetic pesticides in control of crop pests including cabbage pests. Coupled with the expenses on the purchase cost, most specifications of these chemicals are hardly understood by many farmers. This is attributed to illiteracy, complexity and technicality of the language, signs and symbols on these chemicals. Besides, adulteration of agro-chemicals and presence of counterfeits on the market make the pesticides sometimes non responsive hence building up pesticide resistance in the region. According to Pesticide Research Institute (http://www.besnet.world/pesticide-research-institute-pri) frequent use of pesticides can lead to resistant aphid populations. This will only worsen an infestation as higher proportions of the aphid population become pesticide-resistant. In addition, most synthetic pesticides kill beneficial predator insects. Harming natural enemies through the use of broad-spectrum pesticides is counterproductive for aphid management. Among green peach aphid populations, resistance to organophosphates, carbamates and pyrethroid insecticides has been reported (Leanne, 2011; Ahmad \& Akhtar, 2013).

Whereas Neem tree is mostly known for treating Malaria because of its bitter tastes (Marlene, 2014), its natural scent has a repelling property that may drive away or kill crop pests. According to Filho (2005), Neem is a probable source for bio-pesticide, since it presents antibacterial and antivirus properties. Formulation of new bio-insecticides, particularly those based on Neem tree extract, was an exciting option for integrated pest management programs in Kakira. Tang et al. (2002) accept that plant-derived insecticides have various benefits, including selectivity, greater safety for non-target organisms, and compatibility with biological control organisms. Since aphids have built resistance against chemical pesticides; alternative options have to be thought of to ensure controlled aphid pest populations.

\section{Materials and Methods}

\subsection{Study Area}

This study was conducted in Kakira area, lying between $00^{\circ} 30^{\prime} \mathrm{N}$ and $33^{\circ} 17^{\prime} \mathrm{E}, 1800$ meters above sea level in the Northern shores of Lake Victoria. The area has a fertile agricultural land with sandy loam soils. The rainfall pattern is bi-modal, with the first rains received between March and April while second rains are received during July to November each, save for the current climate variabilities. A study by Kiprotich et al. (2013) established that a continuous supply of cabbages throughout season requires farmers to transplant cabbages in the month of October, November and December to target production in the months of December, January and February respectively. Crops grown in the area include sugar cane, maize, tea, coffee, carrots, beans and green vegetables, however, cabbage also is the most popular among the famers in the area. Being a tropical area, temperatures are high all the year round ranging between mean and maximum of $18.2{ }^{\circ} \mathrm{C}$ and $31.2{ }^{\circ} \mathrm{C}$. (Climatological data during the year 2016 at Kakira Sugar Limited). The area is therefore fit for cultivation of the experimental crops without due modification of the conditions.

\subsection{Experimental Design and Treatments}

Determination of the most effective concentration of crude Neem tree extract application on cabbage for aphid control was the study's main objective. Crude extracts were used because the indigenous farmers still use the crude products to save on the costs of production. True field experiments were set out in a randomized complete block design for two growing seasons using Zawadi $F_{1}$ hybrid variety. This cabbage variety is mostly preferred by aphids yet it is the favorite of the farmers. Spacing of $60 \times 60 \mathrm{~cm}$ in between rows and plants respectively was used to enable easy monitoring and comparison of the plots. The plots were treated with Neem tree concoctions prepared as follows: The 2:1 ratio; where $20 \mathrm{~mL}$ of Neem extract were concocted with $10 \mathrm{~L}$ of water, $3: 1$ ratio, where $30 \mathrm{~mL}$ of the Neem extract was concocted with $10 \mathrm{~L}$ of water and a $4: 1$ ratio, where $40 \mathrm{~mL}$ of the extract was concocted with $10 \mathrm{~L}$ of water. Control plots were left under natural environment. Data on the total number of aphid clusters (dead or alive), necrotic damages (leaf perforations, leaf curls), stunting and drum size yield was collected from two hundred fifty six plants, and correlated with the concentration and frequency of application of the Neem extract for two seasons.

This study was carried out in reference to a similar study by Birhanu et al. (2011) where it was indicated that in the control of Brevicoryne brassicae, in Ethiopia, use of chemicals was not a priority but a financial and environmental cost challenge. For the small scale farmers $0.25,0.5$ and $1 \%$ (which concentrations differ from admixtures of this study) in the ratio of $1 / 4: 1 / 2: 1$ were used. The samples were tested in the laboratory against aphid pests by using choice and no choice method. 
During the experiment, cabbage plants were observed for presence and magnitude of aphid clusters, perforations of leaves, curled leaves, stunted plants in order to determine the degree of pest damage. At the end of the season, cabbage yields were determined by weight to establish the treatment performance.

\section{Results and Discussion}

Performance of the different Neem extracts concentrations on the prevalence of aphids on cabbage.

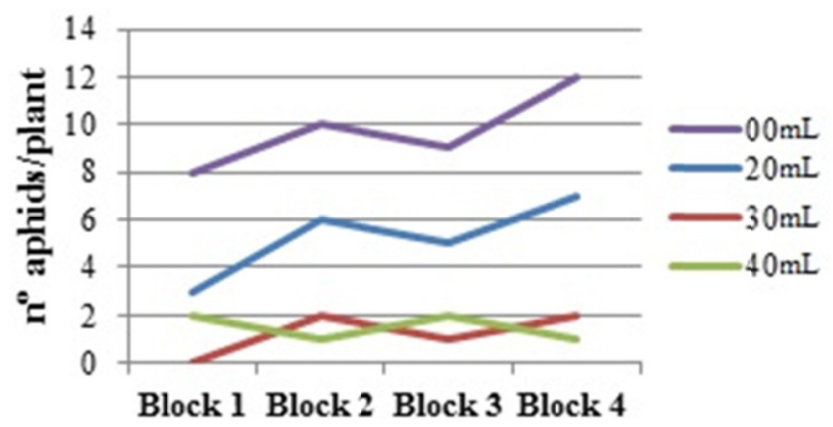

Figure 1. Average number of aphids' cluster per block of cabbage after application of different concentration of admixture of Neem tree extract

Frequency of treatment

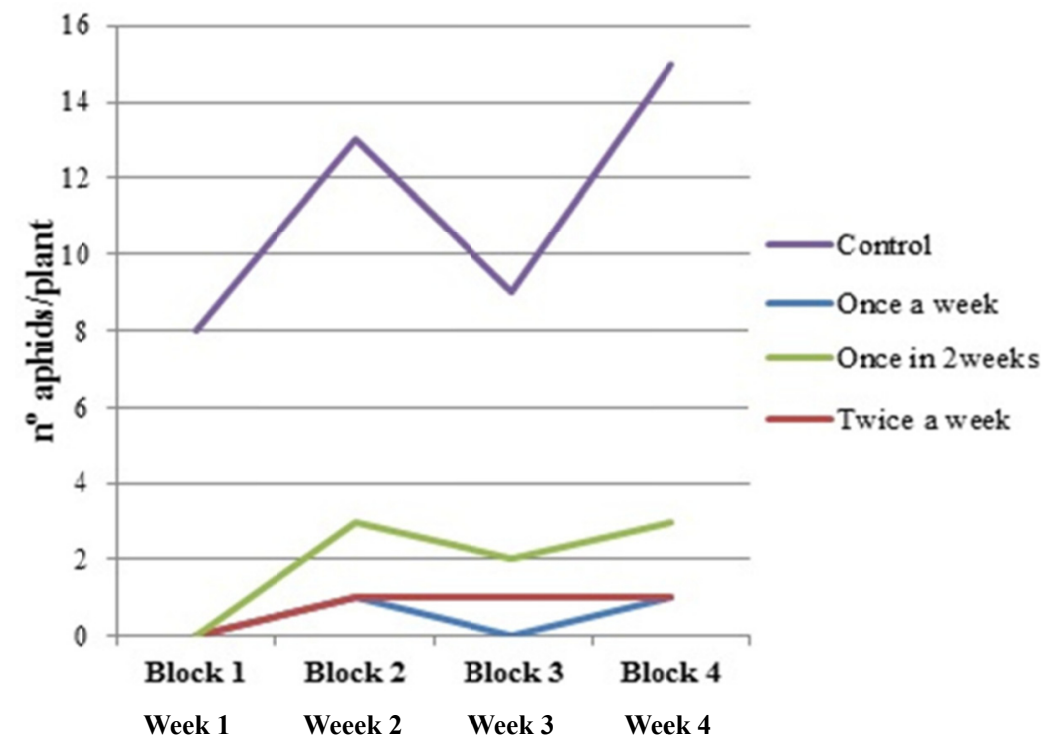

Figure 2. Average number of aphids' cluster per block of cabbage after treatment frequency variation

In Figures 1 and 2 above, the average number of aphids' cluster were more in control plots $(00 \mathrm{~mL}$ treatment $)$ with a total number of 12-15 clusters in the four blocks for both the concentration and frequency treatments. This was followed by $20 \mathrm{~mL}$ whose total number of clusters was 7-3 which was a reduction compared to $40 \mathrm{~mL}$ which had a total number of aphids' cluster at 3-2. Aphids' clusters were less in $30 \mathrm{~mL}$ treated plots at a total number of 2 clusters for all the four blocks. This was evidence that $30 \mathrm{~mL}$ treatment was more effective in controlling the number of aphids below economic injury level. The lower the number of aphids on the plant, the more vigorous the plant grows and attains faster maturity, whereas the higher the number of aphids' cluster on the cabbage plant, the slower the plant growth, remain stunted and the less chances of forming head hence economic loss to the producer. These results were referenced to a similar study by Birhanu et al. (2011) where in the no choice method, methanol extract of Melia seeds treatment showed minimum number (1.33 \pm 0.57$)$ of aphids at $0.25 \%$ concentration. $(0.25 \%)$ of Melia seed treatment recorded only $0.6 \pm 0.57$ aphids of which when we compare results with our results of $30 \mathrm{~mL}$ and $40 \mathrm{~mL}$ concentration of Neem extract which showed minimum 
number of below 2 aphids per plant. This made us conclude that $30 \mathrm{~mL}$ concentration at a frequency of twice a week keeps aphids population below economic injury level. This inspired the design of our research since irrespective of concentration and period of exposure, of the three extracts tested, M. piperita leaf extract and $M$. azadarach seed extract showed promising results. It is upon this background that our methodology was based.

There was a large number of aphids in the control plots compared to plots treated once a week and once in two weeks as shown in (Figure 2). The aphid counts however, progressively decreased with the application of $30 \mathrm{~mL}$ and $40 \mathrm{~mL}$ concentration volumes of Neem extract, applied twice a week and once a week respectively. Spraying twice a week reduces pest load below threshold levels. This field observation concurs with Kumar et al. (2005) and Kumar et al. (2006) whose study established that Neem extracts are strong anti-feedant and repellent, which prevent molting, reduce growth, and affect oviposition thus leading to high mortality in more than 200 insect species including whiteflies and aphids. With the above figures, the researcher concluded that $30 \mathrm{~mL}$ concentration of Neem tree extract on biweekly application stood the best in lowering aphids' population in the cabbage field.

However, another study on insecticide resistance in cabbage aphid carried out in Pakistan reports that aphids developed resistance to chemicals including methomyl, emamectin benzoate, and pyrethroids (cypermethrin, lambdacyhalothrin, bifenthrin and deltamethrin) and neonicotinoids (imidacloprid, acetamiprid, and thiamethoxam). Their resistance level was also found to increase progressively in concurrence with regular use on vegetables (Ahmad \& Akhtar, 2013). It is therefore important to establish alternative methods of dealing with Aphids for example, the use of botanical extract like Neem tree against which Aphids are not likely to develop resistance.

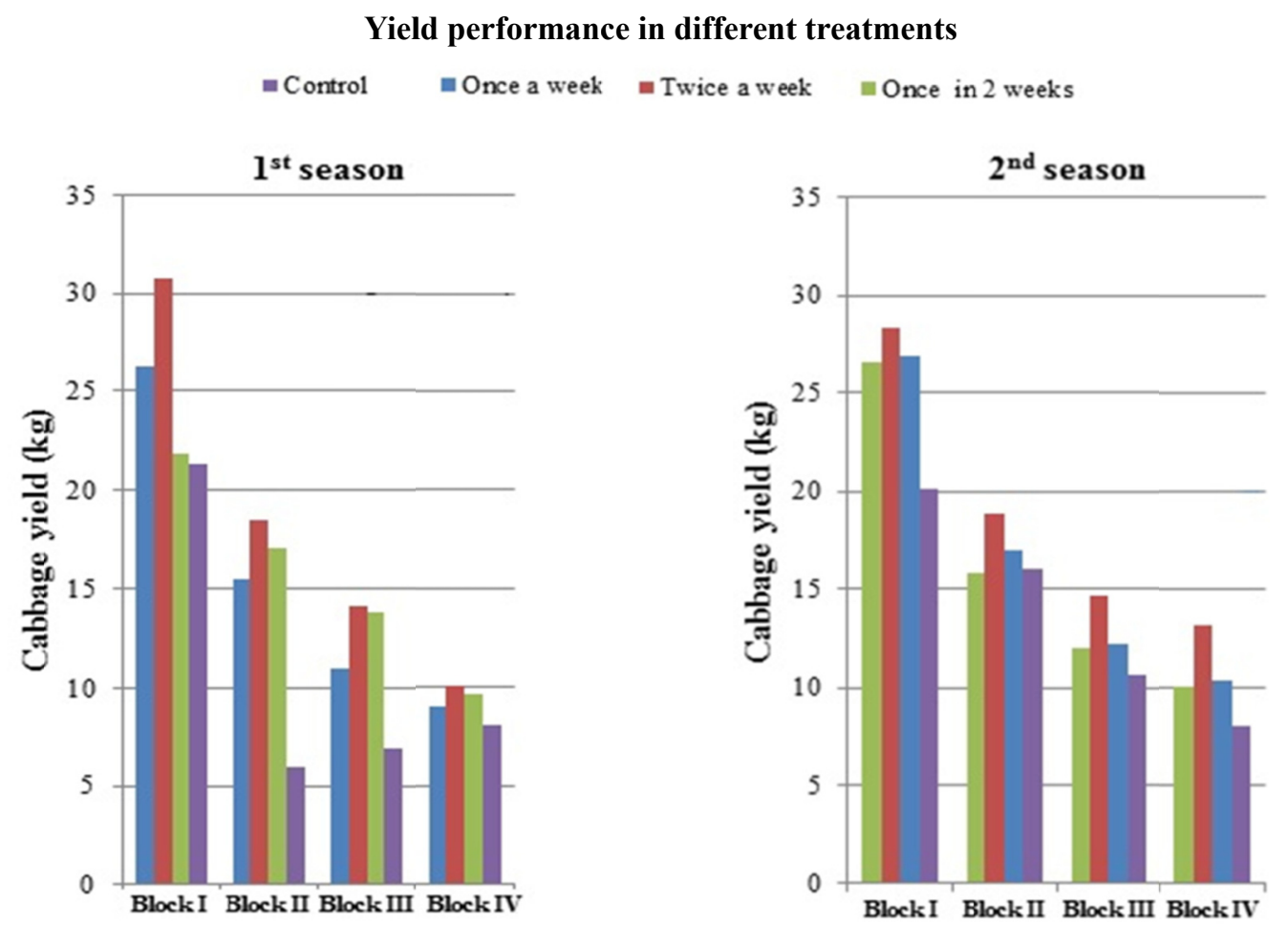

Figure 3. Yield performance for $1^{\text {st }}$ season (left)

Figure 4. Yield performance for $2^{\text {nd }}$ season (right)

Figures 3 and 4 present yields for both first season and second respectively. Yields for Block one were very good for all the treatments for both seasons possibly because pests were few in this block whereas pests were more on blocks 2, 3 and 4 and more damages were caused to these blocks which resulted into yields variation as shown in the figures above.

There was more aphids' prevalence on control plots, followed by plots treated once in 2 weeks and then plots treated once a week. Aphid counts were least in plots treated twice a week. In the same vain, more damage was observed in the same order of plot arrangement as for Aphid prevalence i.e. most on control plots, followed plots 
treated once in 2 weeks, then once a week and least in twice a week treated plots. This was evidence by the total yield variation in all the treatments given. Twice a week treated plots emerge the best in yields with a total of 32.4 and 28.9 kilograms for both first and second season, followed by once a week treated plots with a total yield of 27.3 and 28.4 kilograms for both seasons and once in 2 weeks treated plots with a total yield of 23.7 and 26.3 kilograms and control plots were the least with a total yield of 22.2 and 20.0 kilograms for the two season respectively.

Second season yielded better results than first season which could be attributed to heavier rains in the first season that washed away the treatment quickly and allowed pest reoccurrence. This is in agreement with Bawasakar (2012), who independently noted that cabbage harvest were good during the February summer, It should however, be noted that for both seasons, the 1:3 ratio volume by volume treatment with a biweekly frequency application mounted best in lowering aphids' population below Economic Injury Level. The null hypothesis of the study stated that Neem tree have unique scent that renders them less affected by pests, therefore Neem scent and taste can repel cabbage aphids. In this case, different doses of Neem tree extracts have revealed significance in cabbage aphids control the more frequent application of Neem extracts returning more significant effect on pest population (Table 1).

Table 1. Analysis of variance of three treatment effects on cabbage aphids in relation to control for both seasons

\begin{tabular}{|c|c|c|c|c|c|c|}
\hline Concn & & Sum of Squares & df & Mean Square & $\mathbf{F}$ & Sig. \\
\hline \multirow[t]{3}{*}{ Weight (kilograms) } & Between Groups & 57.269 & 3 & 19.090 & 32.112 & .000 \\
\hline & Within Groups & 149.806 & 252 & .594 & & \\
\hline & Total & 207.075 & 255 & & & \\
\hline \multirow[t]{3}{*}{ Average no. of dead aphids } & Between Groups & 17369.668 & 3 & 5789.889 & 10.049 & .000 \\
\hline & Within Groups & 145187.016 & 252 & 576.139 & & \\
\hline & Total & 162556.684 & 255 & & & \\
\hline \multirow[t]{3}{*}{ Average no. of live pests } & Between Groups & 91527.543 & 3 & 30509.181 & 7.290 & .000 \\
\hline & Within Groups & 1054685.766 & 252 & 4185.261 & & \\
\hline & Total & 1146213.309 & 255 & & & \\
\hline \multirow[t]{3}{*}{ Perforated leaves } & Between Groups & 15.969 & 3 & 5.323 & .694 & .557 \\
\hline & Within Groups & 1933.969 & 252 & 7.674 & & \\
\hline & Total & 1949.937 & 255 & & & \\
\hline \multirow[t]{3}{*}{ Curled leaves } & Between Groups & 52.719 & 3 & 17.573 & 6.149 & .000 \\
\hline & Within Groups & 720.219 & 252 & 2.858 & & \\
\hline & Total & 772.938 & 255 & & & \\
\hline \multirow[t]{3}{*}{ Stunted Plants } & Between Groups & .531 & 3 & .177 & 1.625 & .184 \\
\hline & Within Groups & 27.469 & 252 & .109 & & \\
\hline & Total & 28.000 & 255 & & & \\
\hline
\end{tabular}

Table 2. Analysis of variance of three treatment effect on cabbage aphids in relation to control

\begin{tabular}{|c|c|c|c|c|c|c|}
\hline Frequency & & Sum of Squares & df & Mean Square & $\mathbf{F}$ & Sig. \\
\hline \multirow[t]{3}{*}{ Stunted leaves } & Between Groups & .112 & 3 & .037 & .275 & .843 \\
\hline & Within Groups & 35.155 & 258 & .136 & & \\
\hline & Total & 35.267 & 261 & & & \\
\hline \multirow[t]{3}{*}{ Dead aphids } & Between Groups & 5461.623 & 3 & 1820.541 & 4.661 & .003 \\
\hline & Within Groups & 100762.228 & 258 & 390.551 & & \\
\hline & Total & 106223.851 & 261 & & & \\
\hline \multirow[t]{3}{*}{ Live aphids } & Between Groups & 8986.091 & 3 & 2995.364 & 1.592 & .192 \\
\hline & Within Groups & 485507.665 & 258 & 1881.813 & & \\
\hline & Total & 494493.756 & 261 & & & \\
\hline \multirow[t]{3}{*}{ Perforated leaves } & Between Groups & 17.741 & 3 & 5.914 & 1.138 & .334 \\
\hline & Within Groups & 1341.210 & 258 & 5.198 & & \\
\hline & Total & 1358.950 & 261 & & & \\
\hline \multirow[t]{3}{*}{ Curled leaves } & Between Groups & 41.872 & 3 & 13.957 & 8.945 & .000 \\
\hline & Within Groups & 402.571 & 258 & 1.560 & & \\
\hline & Total & 444.443 & 261 & & & \\
\hline
\end{tabular}


Positive results seen in Table 1 suggest that application of neem tree extracts in the correct dose and spray interval is an alternative approach for the farmers in the control of aphids in horticultural production. Leeson (2001), and Haseeb et al. (2004) independently indicated that Neem-based pesticides tested elsewhere were compatible with arthropod natural enemies of DBM. As a result, Neem-based products are seen as alternatives to the commonly used synthetic pesticides among crucifer growers in the region. A significant number of aphids were counted dead and a highly significant number of normal leaves (Table 2) as a result of application of extract of Neem tree, more specifically in the 3:1 ratio treatments applied biweekly. Farmers in the nearby study area rely on local concoctions of plant extracts. The local dose and the time of application assure the cabbage producers of the reduced stints of aphids on their plants and a subsequent high yield of the cabbage. The overall number of live aphids present in the field depended on the concentration of Neem tree extract admixture application on cabbages and or the frequency of application. The higher the concentration of Neem tree extract admixture applied, the lesser was the number of live aphids observed in the treated plots. Similarly, the frequency of application produced the same results, the more times the concoction was applied; the lesser was the number of pest populations in the field. These results created an assumption that the concentration of Neem tree admixture application on various plots contributed positively in controlling aphids on cabbages. Therefore, even in this situation Neem-based products could be seen as alternatives to the commonly used synthetic pesticides among crucifer growers in the region.

Perforated leaves however, amidst the admixture applications, were still visible. Treatments produced largely insignificant changes for both concentration and frequency treatments of admixture application on cabbages, although perforated leaves were too few to cause an impact on the yield results of the various plots. This further suggests that there are other pests that were responsible for this perforation, though not to the extent of economic injury level. At the level of plant morphology, stunting was considered, vis-à-vis the admixture application. Stunted plants were fewer, an indication that application of the admixture does not interfere with the general growth habits of the crops especially if the soil nutrition is carefully taken care of. Signs of scorching were only observed when applications of $40 \mathrm{~mL}$ in $10 \mathrm{~L}$ of water were used. It is therefore, not necessary to apply concoctions beyond $30 \mathrm{~mL}$ in $10 \mathrm{~L}$ of water twice a week for performance and economic reasons.

\section{Conclusion}

The aim of the study was to address the pest problem in horticultural crops among smallholding farms in Uganda, with a special focus on the effectiveness of the locally concocted Neem tree products in the control of white aphids in cabbage in Kakira sub region. Specific markets are developing in the region for high quality farm products and regional brands, thus compelling the farmers to seek for opportunities to develop efficient, large-scale production systems. The crave for enhanced large scale production resulted in landscapes' destruction with low bio diversity, increased soil erosion, high nutrient input and water pollution. Resource-efficient production schemes that promote biodiversity and landscape aesthetics have to be encouraged. The case of misuse and overuse of pesticide is significant resulting in environmental pollution and widespread diseases like Cancer. In Uganda for example, a number of pesticides like DDT have been in use sometimes against the advice by Environmentalists. Many pesticides are used haphazardly without thorough study and little is done to check their applicability in certain Environments. The lack of user knowledge coupled with compound misuse as a result given room for pests to build resistance to chemical pesticides. Alternatives in view of botanicals are therefore demonstrated. It has been shown in this work that some botanical extracts like Neem have the potential and capacity to manage stubborn pests like Aphids. While it has been a common feeling that only synthetic pesticides have this capacity, farmers should begin to look at such alternatives to Pesticide resistance in many fields. The farmers rely initially on the crude applications of extracts; however, these crude botanicals are dose and frequency dependent for the farmer to achieve positive results from their application. We have therefore proved that Neem concocted in the ratio 3:1 volume by volume applied twice a week is sufficient to manage Aphids in cabbage to well below economic threshold levels.

This study recommends the use of the concoctions at the local level but more study (especially in other Agro ecological regions) is required for its extensive application.

\section{References}

Ahmad, M., \& Akhtar, S. (2013). Development of insecticide resistance in field populations of Brevicoryne brassicae (Hemiptera: Aphididae) in Pakistan. Journal of Economic Entomology, 106, 954-958. https://doi.org/10.1603/EC12233

Bawasakar, V. S. (2012). Why \& When, What \& How Farmer Should Do? Retrieved from http://www. drbawasakartechnology.com 
Boyles, M., Bushong, J., Sanders, H., \& Stamm, M. (2012). Great Plains Canola Production Handbook (pp. 1-60). Kansas State University Agricultural Experiment Station and Cooperative Extension Service, Manhattan, KS, USA.

Cornelius, K., James, A., Charles, T., \& Bob, K. (2006). Forest-based associations as drivers for sustainable development in Uganda. Sustainable Development Centre, Uganda.

Fanindra, P. N. (2001). Synopsis of Use and Economic Value of Pesticides and Chances for Reduced Application Rates at Different Scales in Hindu Kush Region. Institute of Geoecology, Department of Hydrology and Landscape Ecology, Technical University of Braunschweig, Germany.

Filho, W. J. (2005). The Neem Project-Reforestation and Orchard Plantation in Brazil for Industrial Purposes on Sustainable Basis. Retrieved from http://www.crusus.org/home htm files/Wilson Jordao NeemBrazil 2005.pdf

Franke, T. C., Kelsey, K. D., \& Royer, T. A. (2009). Pest Management Needs Assessment for Oklahoma Canola Producers. EPP-7085, Oklahoma Cooperative Extension Service, Stillwater, OK, USA.

Haseeb, M., Liu, T. X., \& Jones, W. A. (2004). Effects of selected insecticides on Cotesia plutellae, endoparasitoid of Plutella xylostella. Bio Control, 49, 33-46. https://doi.org/10.1023/B:BICO.0000009377. 75941.d7

Kakuhenzire, R. M., Haziika, J. J., \& Ssekyewa, C. (1997). Seasonality of major cabbage pests and Inventory of their natural enemies: A case study of Kalengyere, Kabale, Uganda. IPM Horticulture NARO/GTZ Project Scientific Report (p. 35).

Kiprotich, K. C., Kipkorir, E. C., \& Munyao, T. M. (2013). Optimization of Benefits from Cabbage Farming by Staggering Transplanting Dates during the Dry season in Keiyo Highlands, Kenya. Res. J. Chem. Env. Sci., 1(3), 56-62.

Kumar, P., \& Poehling, H. M. (2006). Persistence of soil and foliar azadirachtin treatments to control sweet potato whitefly Bemisia tabaci Gennadius (Homoptera: Aleyrodidae) on tomatoes under controlled (laboratory) and field (netted greenhouse) conditions in the humid tropics. J. Pestic. Sci., 79, 189-199. https://doi.org/10.1007/s10340-006-0133-X

Kumar, P., Poehling, H. M., \& Borgemeister, C. (2005). Effects of different application methods of Neem against sweet potatoWhitefy Bemisia tabaci Gennadius (Homoptera: Aleyrodidae) on tomato plants. J. Appl. Entomol., 129, 889-497. https://doi.org/10.1111/j.1439-0418.2005.01009.x

Leanne, P. (2011). Integrated Pest Management Program. Department of Plant Science and Landscape Architecture; Department of Extension, University of Connecticut, USA.

Leeson, G. R. (2001). Naturally Derived Chemistry (Azadiractin) for Control of CruciferPests in Australia. In N. M. Endersby \& P. M. Ridland (Eds.), The Management of Diamondback Moth and other Crucifer Pests (pp. 347-350). Proceedings of the $4^{\text {th }}$ International workshop, 26-29 November 2001, Melbourne, Australia.

Marlene, A. (2014). The Medicinal Properties of Neem. Mother earth news. (Posted on 8/5/2014, 3:10:00 PM).

Pegadaraju, V., Knepper, C., Reese, J., \& Shah, J. (2005). Premature leaf senescence modulated by the Arabidopsis phytoalexin deficient gene is associated with defense against the phloem-feeding green peach aphid. Plant Physiol., 139(4), 1927-1934. https://doi.org/10.1104/pp.105.070433

Tang, T. Z., Luborsky, L., \& Andrusyna, T. (2002). Sudden gains in recovering from depression: Are they also found in psychotherapies other than cognitive-behavioral therapy? Journal of Consulting and Clinical Psychology, 70, 444-447. https://doi.org/10.1037/0022-006X.70.2.444

Zachary, B. S. (2015). Cabbage, Broccoli \& Other Cole Crop Insect Pests. Clemson Extension, Clemson University Cooperative Extension Service. Retrieved December 23, 2016, from https://www.clemson.edu/ extension/hgic/pests/pdf/hgic2203.pdf

\section{Copyrights}

Copyright for this article is retained by the author(s), with first publication rights granted to the journal.

This is an open-access article distributed under the terms and conditions of the Creative Commons Attribution license (http://creativecommons.org/licenses/by/4.0/). 